\title{
Review
}

\section{Political science pedagogy: A critical, radical, and utopian perspective}

\author{
William W. Sokoloff \\ Palgrave Macmillan, London, 2020, xvii+172pp., \\ ISBN: 978-3030234898
}

Contemporary Political Theory (2021) 20, S148-S151. https://doi.org/10.1057/s41296020-00407-3; published online 28 May 2020

Political Science Pedagogy is a book that has all the wrong arguments and yet arrives at all the right conclusions. 'All' is perhaps too strong in both cases, but there is a strong temptation to respond to William Sokoloff's hyperbole with more hyperbole - and this is a text filled with rhetorical embroidery meant to inflame the passions. For those already inclined to agree, Sokoloff's intensity is a virtue as it serves to emphasize the importance of his subject matter, but it also proves a significant barrier to drawing in new allies who would benefit from considering his conclusions.

Sokoloff's book is divided into five chapters, and Sokoloff advises his readers that '[i]f a particular chapter does not interest you, kindly skip it and move on to the next' (p. 21). Yet those who disregard individual essays will likely find the text odd, inconsistent, and occasionally infuriating as it only really makes sense as a comprehensive whole. As becomes apparent the further one reads, Sokoloff is not concerned with the state of political theory education for its own sake; rather, he seeks to reorient pedagogical practices towards protecting those at the margins of an increasingly fractured American political project. There are arguments here that can stand alone as contributions to the discipline, but this is an intensely personal book: Sokoloff's experiences in the classroom flow into his political persuasions which inform his arguments in this book. It is difficult to distinguish between these different modes, and the book paints a portrait of its author as much as it issues a call to critical pedagogy in political theory classrooms. Sokoloff's character really shines on each page, and one of the greatest achievements of this text is that it generates in the reader the distinct impression that his classes are an experience unto themselves.

Its affective appeal positions Sokoloff's book as the progressive and optimistic counterpart to Allan Bloom's nostalgic and melancholy Closing of the American Mind. What the two books share is an intimate look at their authors, an intense desire to save political theory education, and a willingness to eschew academic

(c) 2020 Springer Nature Limited. 1470-8914 Contemporary Political Theory Vol. 20, S3, S148-S151 
norms and conventions to do so. Bloom made his case by sidestepping academia altogether and appealing directly to American conservative intellectuals. He was well aware that his approach would find limited purchase among his teaching colleagues, so he targeted a broader audience of non-academic allies. Sokoloff, too, appears to address a wider audience than fellow progressive educators, but he is so committed to an unapologetic radicalism that moments of appeasement never seem to last.

Sokoloff claims that his radical pedagogy is "not referring to some form of political extremism and belligerent activism', but the very act of 'expand[ing] the political horizons of students beyond mainstream perspectives' is political extremism (p. 17; 16). He is clear that this is part of the project he is engaged in: 'Radial analysis is the precondition for new forms of research, thought and political struggle ... We must think outside the dominant frames of reference' (p. 17). Sokoloff softens his language at points, yet it is never altogether clear who he is doing this for, because he makes no effort to hide that his critical, radical, utopian pedagogy is opposed to 'the current horizon of cruelty intrinsic to neoliberal authoritarian politics, socialism for the non-working rich and transfer of wealth upward via theft of public funds and tax breaks for billionaires' (p. 19). Why, then, are there moments in which he strives for non-partisanship? If the current education regime 'positions itself as a conservative force' and he would prefer to replace it with a progressive force, who is served by this charade (pp. 2-3)? Are there neoliberals eager to hand over the levers of power to radical reformers? Are there progressive educators who think the key to '[f]ighting for the democratization of democracy' can be found in compromise with neoliberalism (p. 29)?

Taken independently, each individual chapter might be best understood as a deliberately controversial attack on conventional disciplinary wisdom: Sokoloff offers a novel account of similarities between Leo Strauss and Sheldon Wolin; he provides a rigorous critique of the Socratic method from both our contemporary vantage and on Plato's terms; he suggests that Frantz Fanon's subversive forms of pedagogy are an invaluable classroom tool in highlighting the philosophical roots of racial injustice and inequality in America; he argues that political theory is uniquely situated to make use of online learning to enhance pedagogical practices and offers clear examples for other instructors to draw on; and, in his least provocative chapter, he applies Paulo Freire's work on critical pedagogy to broadly critique contemporary political science education as insufficiently committed to human flourishing. It is an eclectic and playful mix of topics, but it manages to avoid feeling disparate because Sokoloff's focus throughout is on 'the importance of student voice, making course material relevant and connecting it to the lives of our students' (p. 25).

Despite the connections Sokoloff makes between the topics, the breadth of his approach at times comes at the cost of depth. Consider his claim about Strauss and Wolin that, '[a]s political theorists, they are not as different from each other as we

(c) 2020 Springer Nature Limited. 1470-8914 Contemporary Political Theory Vol. 20, S3, S148-S151 S149 
might believe' (p. 30). What Sokoloff wants to show us is that, contrary to their surface disagreements, they agree on the purpose of political theory: maintenance of the status quo. For Strauss this involves 'legitimating inequality, inculcating deference to aristocrat intellectuals, keeping the masses pacified and ensuring law and order'; for Wolin it is because his 'political theory as a vocation ... empowers and elevates the practitioner of political theory to the status of protector of the threatened tradition' (p. 32; 42). Yet Sokoloff ignores that Strauss immersed himself in non-traditional thinkers like Al-Farabi, Averroes, and Maimonides. And although he rightly notes that Strauss believed political theory was not for everyone, Strauss' conception of liberal education was meant to force people to engage with uncomfortable ideas that they might prefer to avoid. The claim that 'Strauss believed common people are incapable of reading anything more complicated than a comic strip' is certainly provocative, but it mistakes the causal order (p. 33). Strauss did not think all people were suited to a lifetime of political theory - much like I am ill-suited to practice medicine by virtue of my squeamishness - but he was an advocate for liberal education precisely because he regarded difficult and complex texts as uniquely capable of forcing people to consider that which is uncommon. Of course, if we consider the United States to be his model, a properly liberal education is outside the reach of the vast majority of people, and if you do not know that you are in the Cave, it is particularly difficult to consider the possibility of leaving it. The American education system already rests upon a number of structural inequalities which both prevent the realization of Strauss' prescriptive project and magnify the inequalities that naturally emerge from a widespread liberal education. While Sokoloff arrives at this conclusion, the arguments he makes to do so are more provocative than they are an accurate representation of his interlocutors' views.

His novel premises are not themselves a problem. Even when I was skeptical at the outset, for example, as with his defense of online political theory education, the ideas draw you in. What is largely missing are sufficient nuances to convince those who do not already agree. His opposition to the Socratic method is thoroughly interesting, but it is another moment where his introductory equivocations seem curious, given that his hostility to the tradition leaps off the page. At one point, he passingly compares Socrates' behavior to that of Brett Kavanaugh during his confirmation hearing. It is the kind of incendiary comparison which seems perfectly suited to classroom discussions and highlights Sokoloff's commitment to a radical critique of the tradition, but it comes at the cost of alienating readers who are turned off by its ideological tone.

This text is hardly overfull with similarly inflammatory rhetoric, but this instance is instructive as to Sokoloff's approach: while he has interesting arguments and wholly legitimate critiques, his provocative style undermines them for the audience most in need of hearing them. Throughout the book, Sokoloff speaks to how important it is for students to trust their instructors, but he fails to take this 
same approach with regard to his readers. Political Science Pedagogy is fertile soil for those already committed to critical pedagogy and revolutionary utopian politics. What is too bad is that this book promises to speak to a broader audience, and, although Sokoloff seems both interested and capable of doing so, it ultimately comes up short on that front, because he is more committed to being right than he is to being persuasive.

Publisher's Note Springer Nature remains neutral with regard to jurisdictional claims in published maps and institutional affiliations.

Steven Orr

Carleton University, Ottawa, ON K1S 5B6, Canada

StevenOrr@cmail.carleton.ca 